\section{$\underset{\substack{\text { hommes } \\ \text { \& migrations }}}{ }$}

\section{Hommes \& migrations}

Revue française de référence sur les dynamiques

migratoires

1319 | 2017

Réfugiés et migrants au Liban

\title{
Les enfants de Sabra
}

\section{Hassan El-Abdallah}

\section{CpenEdition \\ Journals}

\section{Édition électronique}

URL : http://journals.openedition.org/hommesmigrations/3963

DOI : 10.4000/hommesmigrations.3963

ISSN : 2262-3353

\section{Éditeur}

Musée national de l'histoire de l'immigration

\section{Édition imprimée}

Date de publication : 1 octobre 2017

Pagination : 39

ISBN : 978-2-919040-39-1

ISSN : $1142-852 X$

\section{Référence électronique}

Hassan El-Abdallah, « Les enfants de Sabra », Hommes \& migrations [En ligne], 1319 | 2017, mis en ligne le 01 octobre 2020, consulté le 08 janvier 2021. URL : http://journals.openedition.org/ hommesmigrations/3963; DOI : https://doi.org/10.4000/hommesmigrations.3963 


\section{LES ENFANTS DE SABRA}

Par HASSAN EL-ABDALLAH ${ }^{1}$.

Les larmes ont presque jailli de mes yeux quand j'ai vu pour la première fois cet enfant portant un grand sac qui, s'il n'était pas plus lourd que lui, pesait exactement son poids. Il criait : «Des sacs, des sacs, qui veut des sacs? "Il vendait des petits sacs en plastique. Sa voix ressemblait à celle d'un chaton épuisé par la faim et éreinté par le froid.

Un enfant au lourd fardeau marche dans les rues d'une ville saturée d'habitants venus de différents pays et de diverses races et couleurs : blancs, jaunes et noirs. Ces derniers luttent pour leur vie, leur sécurité et la pérennité de leur existence. Comme tous les êtres humains, ils recherchent uniquement leur subsistance. Et tous les nationalismes se brisent quand on cherche un morceau de pain.

Il survit dans un corps frêle, des cheveux frisés et un visage au sourire triste, teintée d'une légère gaieté. Ce qui l'a poussé à faire ce travail pénible, c'est la guerre qui a broyé le pays et les hommes comme le moulin écrase le blé.

J'ai avalé ma salive et insulté intérieurement cette guerre et ceux qui sont responsables de son éclatement. Il passait devant moi tous les matins, je lui achetais les sacs pour le magasin dans lequel je travaillais. Ses yeux étaient encore emplis de sommeil. Il portait les sacs et traînait les pieds. Ce qui m’a le plus peiné, c'est de le voir le matin de la fête dans ses nouveaux habits : un pantalon bleu et une chemise marron de la couleur de ses chaussures, les cheveux coupés et coiffés avec du gel. Il avait mis sa marchandise dans un nouveau sac qu'il portait sur son dos. Il criait d'une voix fine avec un brin de joie à l'approche de la fête, source de gaieté malgré toutes les souffrances qu'ils endurent lui, sa famille et beaucoup d'autres réunies par la souffrance infligée par la migration. Tous craignent pour les enfants et la dignité de la famille. Ils partent à la recherche de quoi survivre, tout en supportant les affres de l'exil et la rudesse de leurs frères du pays d'accueil, les injures et les humiliations, jusqu'aux coups et à l'extorsion d'argent. Car, si tous ne sont pas concernés, une grande proportion de personnes maltraite les réfugiés, animée par un communautarisme mesquin et un mauvais esprit.

Un enfant attaché à la vie avec son jeune âge et son corps frêle qui ne supporte ni les chaleurs de l'été ni le froid des nuits d'hiver. Il a posé son sac par terre et soupiré tristement malgré son visage souriant. Avec ses yeux émouvants teintés d'un imperceptible regret, il regarde les enfants aux habits neufs comblés de jouets qui vivent en paix dans leur pays, comme s'il se souvenait du jour de fête dans son beau pays qui part aujourd'hui à la dérive, avec le feu du communautarisme, la guerre civile et la guerre internationale. Il se rappelle les balançoires de son petit quartier, la compagnie de ses amis, de ses parents, et la joie, les disputes et les jeux.

Je lui ai pris des sacs, il a pris son argent : «- Tu travailles le jour de la fête? » Il a répondu : « Je travaille jusquà midi et je vais aux balançoires. "Il a porté le sac facilement après que je l'ai vidé la moitié de son contenu et il est parti... "Les deux derniers paquets, qui achète les sacs?"

Il s'est absenté une période, puis je l'ai revu et lui ai demandé comment il allait. Il m’a répondu qu'il allait à l'école pour les réfugiés et qu'il apprenait làbas. J'ai été très content pour lui et je lui ai demandé qui travaille maintenant à sa place ? Il m’a dit gaiement: " Ma mère m’a dit : "Va à l'école mon fils, Dieu ne nous oublie pas et nous n'allons pas mourir de faim." " Ces mots simples m'ont touché. Ce petit enfant m'a appris à vivre avec patience et fermeté, à me contenter de ce que la vie donne, en attendant les jours à venir, qui viendront seuls de toute manière. 